\title{
Effect of Mineral Fertilization and Some Organic Compounds on Faba Bean Crop in some Soils at the New Valley, Egypt
}

\author{
H.A. Fawy, S.M. Ibrahim and M.F.A. Hussein \\ Soil Fertility and Microbiology Department, Desert Research \\ Center (DRC), Cairo, Egypt.
}

IELD experiments were carried out during two successive years in
two sites at the New Valley, Egypt. The first site was clay soil
located at El-Kaser Village, El-Dakhlla Oasis and the second site was
sandy soil located at El-Monera village, El-Kharaga Oasis. Seeds of
faba bean variety Rebaya were cultivated in both the two studied
locations. This study was designed in order to improve the yield of
faba bean under conditions of the New Valley soils by the
combination of mineral fertilizers and some organic compounds.
Nitrogen (N), phosphorus (P) and potassium (K) fertilizers were
applied as soil and foliar applications at different rates. Different rates
of boron (B), molybdenum (Mo) and zinc (Zn) were applied as foliar
applications. Some organic compounds viz., humic acid (HA), amino
acid (AA), ascorbic acid (AS) and licorice extract (LC) were
combined with mineral fertilizers.

Application of N, P and $\mathrm{K}$ along or with $\mathrm{B}, \mathrm{Mo}$ and $\mathrm{Zn}$ increased yield and nutrient contents of faba bean. The treatments of mineral fertilizers and organic compounds further increased yield components, nutrient contents, total antioxidants activity and total phenol of faba bean in both soils. Organic compounds increased the yield and their effectiveness could be arranged as: $\mathrm{LC}<\mathrm{HA}<\mathrm{AA}<\mathrm{AS}$ in ascending order. Mixing these compounds had higher effect on yield and nutrient contents than individual applications. Their effect could be arranged in ascending order as: $\mathrm{LC}+\mathrm{HA}<\mathrm{LC}+\mathrm{HA}+\mathrm{AA}<\mathrm{AS}+\mathrm{AA}$ $+\mathrm{HA}<\mathrm{AS}+\mathrm{AA}+\mathrm{HA}+\mathrm{LC}$. The AS had the highest effect on total phenols and antioxidants. The LC had higher values than HA and AA treatments, respectively. The most effective treatment in the yield was (AS + AA + HA + LC $+\mathrm{N}_{2} \mathrm{P}_{2} \mathrm{~K}_{2}+$ with micronutrient), which achieved 5.95 and $2.73 \mathrm{t} \mathrm{fed}^{-1}$ of shoot and seed, respectively in sandy soil. In clayey soil, these values were 8.91 and $4.30 \mathrm{t} \mathrm{fed}^{-1}$, respectively. Regarding total antioxidants and phenols, the same treatment could achieve the highest values in both soils recording 216 and $227 \mu \mathrm{g}$ ascorbic acid $\mathrm{ml}^{-1}$ extract and 791 and $876 \mu \mathrm{mol}$ of gallic acid $\mathrm{ml}^{-1}$ extract for shoot and seed, respectively in sandy soil. These values were 231 and $243 \mu \mathrm{g}$ ascorbic acid $\mathrm{ml}^{-1}$ and 891 and $983 \mu \mathrm{mol}$ of gallic acid ml ${ }^{-1}$ in clayey soil, respectively. This study demonstrated that incorporating some organic compounds along with mineral fertilizers has a beneficial effect on yield and quality of faba bean.

Keywords: Mineral fertilizers, Organic compound, Yield, Faba bean, Sandy and clay soils in New Valley. 
Several studied have reported that combing macro- and micronutrients as soil and foliar applications have the ability to improve plant quantity and quality yield. For instance, foliar N, P and Mo application enhanced the growth and nutritional status of common bean seed (Eduardo et al., 2010). In the same trend, Kandil et al. (2013) observed that the highest number of pods per plant, length of pod and protein content were produced when $\mathrm{P}$ and Mo were foliar applied to common bean. Growth parameters of mungbean plant enhanced with increasing the levels of P (Ali et al., 2014). Abd El Hamid et al. (2010) concluded that soil and foliar applications of $\mathrm{K}$ to faba bean increased the yield quantity and quality as well as plant resistance to foliar diseases. Combing $\mathrm{N}, \mathrm{P}$ and $\mathrm{K}$ foliar applications increased the yield and nutritional status of faba bean in sandy soil (Fawy, 2010). However, application of $\mathrm{N}$ fertilizer in soil combined with foliar $\mathrm{Zn}$ recorded the highest yield parameters of faba bean (Bozorgi et al., 2011). Jasim and obaid (2014) observed that foliar spray of N, P and K with B increased faba bean yield and seed quality. Ati and Ali (2011) reported that foliar application of B achieved highest yield of faba bean and improved water use efficiency. Furthermore, Sharaf et al. (2009) reported that hotosynthetic pigments, soluble carbohydrates, soluble proteins, total phenols, levels of gibbrellic acid and indole acetic acid in broad bean and lupin plants increased with foliar application of B and $\mathrm{Zn}$.

Several studies have reported that foliar application of some organic compounds could enhance yield and biochemical contents of many crops. For example, Sadak et al. (2013) reported that foliar application of indole acetic acid and kinetin individually or in combination had positive effects on photosynthetic pigments, total carbohydrate, polysaccharide, free amino acid, proline and total phenolic contents of faba bean. Abou EL-Yazied and Mady (2012) concluded that foliar application of $\mathrm{B}$ and yeast extract either individually or mixture to broad bean increased yield components.

Amino acids had many functions in plant such as protein synthesis, stress resistance, photosynthesis, action on the stomas, chelating effect, activation of phytohormones, pollination with fruit formation and equilibrium of soil flora, as reported in Ortiz-Lopez et al. (2000), Abd El-Samad et al. (2010) and Gioseffi et al. (2012). Application of humic substances could increase morphological criteria, metabolism, mineral contents and yield of many crops (Fahramand et al., 2014; Canellas \& Olivares, 2014; and El-Bassiouny et al., 2014). Khaled and Fawy (2011) concluded that foliar application of humic substances increasing nutrients uptake and leaf water retention under salt and water stress conditions.

Application of licorice extract to plant strengthened the germination process and increased the plant's ability to withstand and resist the salinity and drought stress. For example, several studies have reported that licorice extract elevated the chlorophyll content and increased anthocyanin content and thus the resistance against phytopathogenic (Scherf et al., 2010; Srivastava et al., 2009; and Schuster et al., 2010).

Egypt. J. Soil Sci. 56, No. 1 (2016) 
Antioxidants have the ability to protect cells from the damage caused by free radicals; therefore, the yields and quality of plants were improved when high level of antioxidants were applied in fruits and vegetables. The key components of antioxidants are antioxidant enzymes, ascorbic acid, carotenoids and flavonoids (Hamid et al., 2010; Gill \& Tuteja, 2010; Agatia et al., 2012; and Brunetti et al., 2013).

El-Ghamry et al. (2009) reported that foliar application of humic and amino acids improved growth and mineral content and decreased the damage of chocolate spot and rust diseases in faba bean. Gad El-Hak et al., (2012) also reported that foliar application of humic acid produced highest quantity and best quality of green pods and dry seed yield of peas plants. Shafeek et al. (2013) stated that foliar application of humic acid recorded highest values of growth and protein content of broad bean seed. Ibraheim (2014) reported that foliar application of yeast extract and Mega Power (19\% humic acid, 2\% fulvic acid, $5 \%$ free amino acids, $0.5 \% \mathrm{Zn}$ chelated, $0.025 \% \mathrm{Fe}$ chelated, $0.05 \% \mathrm{Mn}$ chelated and 2\% K-citrate) increased N, P and T.S.S (\%) in pea plant. Amin et al. (2014) reported that foliar application of thiourea and aspartic acid (amino acid) individual or in combination improved the yield, nutrients values and quality of faba bean seed. Spraying licorice root extract in a concentration of $4 \mathrm{gm} \mathrm{L}^{-1}$ and $\mathrm{Zn}$ in a concentration of $100 \mathrm{mg} \mathrm{L}^{-1}$ achieved the highest yield parameters of berry plant (Zuhair and Mohammed 2010). However, foliar applications of licorice roots extract along with amino-K and yeast recorded highest yields of grape trees (Al Dulaimy and Jumaa 2012). Azooz et al. (2013) stated that foliar application of ascorbic acid improved salt tolerance and nutrient contents of broad bean. Abdelgawad (2014) reported that the foliar application of ascobin (ascorbic acid and citric acid at ratio 2:1) improved salt tolerance, total soluble sugars, proline, glycine and N, P and K contents of cowpea plant. Keeping in view the above mentioned points, this study was designed in order to optimize quality and quantity of faba bean yield by integrating mineral fertilizers and some organic compounds in two different soils at the New Valley, southern Egypt.

\section{Material and Methods}

Field experiments in two successive seasons (2012/13-2013/14) were carried out in split-split plot design with three replications in two sites at the New Valley, Egypt. The first experiment carried out at El-Monera, El-Kharaga Oasis location at $27^{\circ} 34^{\prime} 21^{\prime \prime} \mathrm{N}$ and $30^{\circ} 57^{\prime} 56^{\prime \prime} \mathrm{E}$ representing sandy soils, while the second experiment was at Al-Kaser location at $28^{\circ} 21.9^{\prime} 28^{\prime \prime} \mathrm{N}$ and $31^{\circ} 27.6^{\prime} 25^{\prime \prime}$ E representing clay soils. Analytical data of the studied soils are presented in Table (1). Micronutrients ( $\mathrm{Zn}, \mathrm{B}$ and Mo) treatments constituted the main plots; $\mathrm{N}, \mathrm{P}$ and $\mathrm{K}$ treatments constituted the sub plots, and the organic compounds treatments were maintained in the sub-sub plots (Table 2). The plot area was (9x10m) $90 \mathrm{~m}^{2}$ at Al-Kaser location while was $(8 \times 8 \mathrm{~m}) 64 \mathrm{~m}^{2}$ at the El-Monera location. The irrigation system in both sites was flood irrigation. Faba bean 
variety Rebaya was cultivated at $20 \mathrm{~cm}$ between plants in row, $40 \mathrm{~cm}$ apart in both locations. Before cultivation faba bean seeds were treated with rhizobium bacteria according to El Habbasha et al. (2007).

TABLE 1. Some physical and chemical properties of the soil and chemical analyses of the irrigation water at the experimental sites.

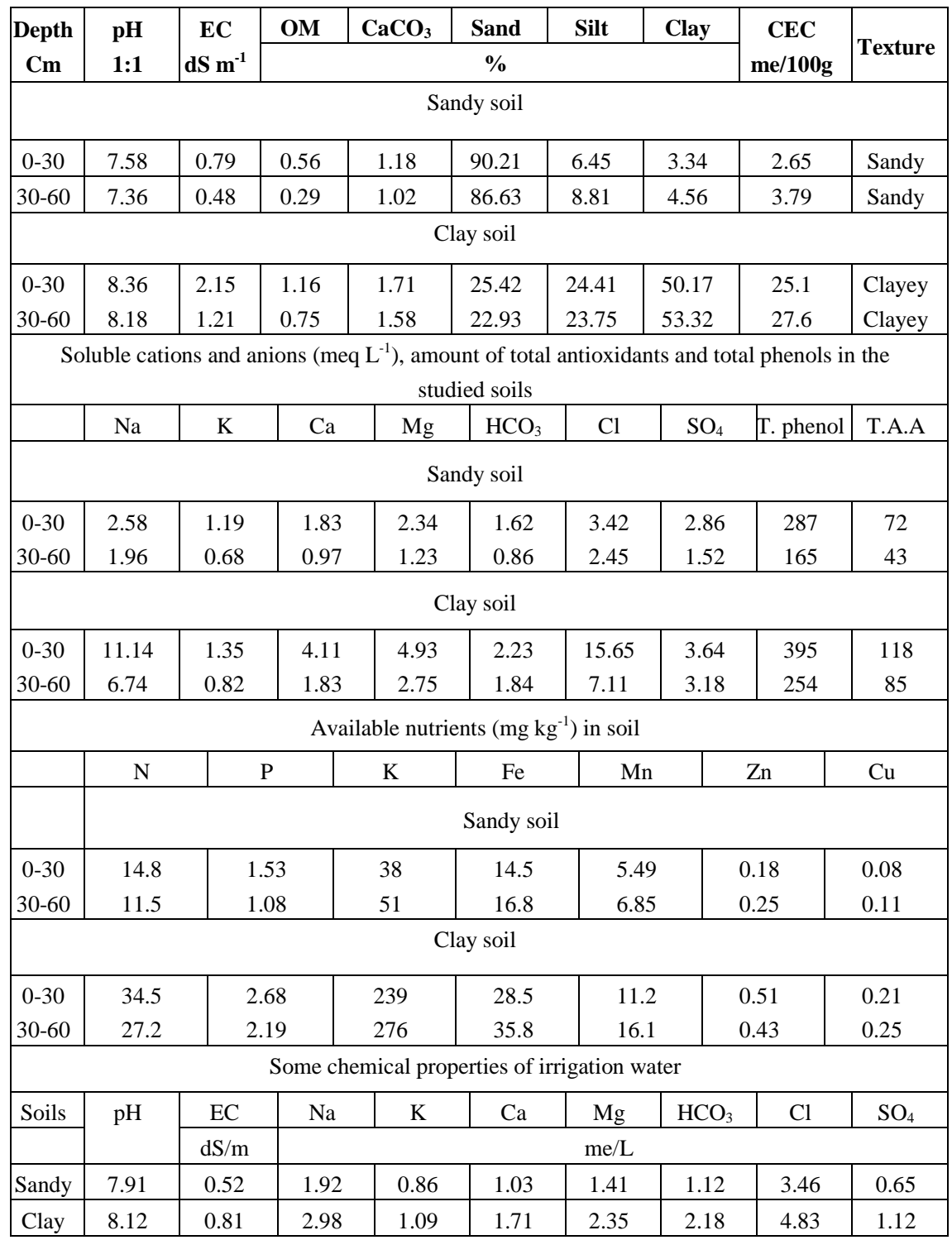

Egypt. J. Soil Sci. 56, No. 1 (2016) 
TABLE 2. The treatments of mineral fertilizers and organic compounds in the experimental sites.

\begin{tabular}{|c|c|c|c|c|c|c|}
\hline Fertilizers & \multicolumn{3}{|c|}{ Sandy soil } & \multicolumn{3}{|c|}{ Clay soil } \\
\hline \multicolumn{7}{|c|}{ Soil fertilizers $(\mathrm{kg} / \mathrm{fed})$ for the studied soils } \\
\hline & $\mathrm{N}$ & $\mathrm{P}_{2} \mathrm{O}_{5}$ & $\mathrm{~K}_{2} \mathrm{O}$ & $\mathrm{N}$ & $\mathrm{P}_{2} \mathrm{O}_{5}$ & $\mathrm{~K}_{2} \mathrm{O}$ \\
\hline $\mathrm{N}_{1} \mathrm{P}_{1} \mathrm{~K}_{1}$ & 50 & 25 & 40 & 40 & 35 & 20 \\
\hline $\mathrm{N}_{2} \mathrm{P}_{2} \mathrm{~K}_{2}$ & 70 & 50 & 60 & 60 & 65 & 40 \\
\hline \multicolumn{7}{|c|}{ Foliar of micronutrients applied at two rates (with and without) } \\
\hline Micronutrients & \multicolumn{6}{|c|}{ Applied at two rates $\mathrm{B}(0,50 \mathrm{ppm}), \mathrm{Mo}(0,5 \mathrm{ppm})$ and $\mathrm{Zn}(0,300 \mathrm{ppm})$} \\
\hline \multicolumn{7}{|c|}{ Foliar of macronutrients applied at one rate for all the studied treatments and soils } \\
\hline Dose A & \multicolumn{6}{|c|}{ first dose $(0.75 \mathrm{~kg}$ of $20 / 20 / 20) / 200 \mathrm{~L}$} \\
\hline Dose B & \multicolumn{6}{|c|}{ second dose $(0.5 \mathrm{~kg}$ of $20 / 20 / 20+0.25 \mathrm{~kg}$ of $0 / 80 / 0+0.4 \mathrm{~kg} 0 / 0 / 50) / 200 \mathrm{~L}$} \\
\hline Dose $\mathrm{C}$ & \multicolumn{6}{|c|}{ third dose $(0.4 \mathrm{~kg}$ of $20 / 20 / 20+0.35 \mathrm{~kg}$ of $0 / 80 / 0+0.5 \mathrm{~kg} 0 / 0 / 50) / 200 \mathrm{~L}$} \\
\hline \multicolumn{7}{|c|}{ Organic compounds applied at two rates as foliar solutions $(0,1000 \mathrm{ppm})$} \\
\hline Humic acid & \multicolumn{6}{|c|}{$23.3 \mathrm{~g}$ of humic acid $86 \%$ dissolved in $20 \mathrm{~L}$} \\
\hline Amino acid & \multicolumn{6}{|c|}{$100 \mathrm{ml}$ of amino acid $20 \%$ dissolved in $20 \mathrm{~L}$} \\
\hline Ascorbic acid & \multicolumn{6}{|c|}{$20 \mathrm{~g}$ of ascorbic acid $100 \%$ dissolved in $20 \mathrm{~L}$} \\
\hline licorice & \multicolumn{6}{|c|}{$800 \mathrm{ml}$ of licorice extract $(0.5 \mathrm{~kg} / 20 \mathrm{~L})$ dissolved in $20 \mathrm{~L}$} \\
\hline
\end{tabular}

$\mathrm{N}, \mathrm{P}$ and $\mathrm{K}$ fertilizers were applied as soil application at two rates and a rate of foliar application at three equal split doses (Table 2). $\mathrm{N}$ and $\mathrm{K}$ were applied in three equal split doses that were applied after 25, 50 and 75 days after sowing, while the whole rate of $\mathrm{P}$ was applied with soil preparation. The foliar mineral fertilizers were applied after one week of $\mathrm{N}$ and $\mathrm{K}$ soil application. $\mathrm{N}$ was applied as ammonium nitrate, $\mathrm{P}$ as calcium superphosphate and $\mathrm{K}$ as potassium sulfate. $\mathrm{B}$ as boric acid at $50 \mathrm{mg} \mathrm{L}^{-1}$, Mo as ammonium molybdate at $5 \mathrm{mg} \mathrm{L}^{-1}$ and $\mathrm{Zn}$ as zinc sulphate at $3005 \mathrm{mg} \mathrm{L}^{-1}$ were applied at two rates as foliar application. The studied organic compounds were humic acid (HA), amino acid (AA), ascorbic acid (AS) and licorice extract (LC). Two rates of organic compounds were applied at the same times of foliar mineral application (Table 2). Farm yard manure was applied at one rate of 10 and $20 \mathrm{~m}^{3} \mathrm{fed}^{-1}$ in clay and sandy soils, respectively, with soil preparation for sowing.

Soil samples were collected at two layers $(0-30$ and $30-60 \mathrm{~cm})$ before sowing for physical and chemical analyses. Plant samples were collected at physiological maturity. Faba bean yield parameters such as weight of shoot and seed (ton fed ${ }^{-1}$ ) were recorded. Soil and plant samples were analyzed for macro and micronutrients according to Cottenie et al. (1982). Different analyses of the studied soils were accomplished according to Page et al., 1984; and Klute, 1986). Measurements of total antioxidants and total phenol in soil and faba bean plants were estimated according to Rimmer (2009). The analysis of variance (ANOVA) was used to determine the effect of treatments on yield parameters. Least significant differences (LSD) test was used to determine the differences between treatments means at 5\% probability level according to Gomez and Gomez (1984). 


\section{Results and Discussion}

Effect of mineral fertilizers and organic compounds on yield of faba bean

Data in Table 3 show that the highest yields of faba bean were obtained when the application rates of $\mathrm{N}, \mathrm{P}$ and $\mathrm{K}$ fertilizers were increased and micronutrients were foliar applied in both soils. The organic compounds application increased yield parameters in the presence of mineral fertilization. The best treatment for yield parameters in the two studied soils was $\left(\mathrm{AS}+\mathrm{AA}+\mathrm{HA}+\mathrm{LC}+\mathrm{N}_{2} \mathrm{P}_{2} \mathrm{~K}_{2}+\right.$ with Micronutrients) which recorded 5.95 and 2.73 ton fed $^{-1}$ for shoot and seed in sandy soil, while in the clay soil were 8.91 and 4.30 ton fed $^{-1}$, respectively. This could be due to the integration between mineral fertilizers and organic compounds optimized the nutritional status of faba bean and suppressed the constraints of growth and consequantely improved plant growth and yield. These results agreeable with those obtained by Al Dulaimy \& Jumaa (2012); and Jasim \& obaid (2014).

Regarding the organic compounds either individual or in combinations, their foliar applications were increased quantity and quality of faba bean. Applications of organic compounds as individual forms were lower in yield than in combination forms. The LC was lowest in increasing shoot and seed yield compared with control treatment was an average increase of 47.0 and $50.4 \%$ in sandy soil; While were about 43.2 and $49.8 \%$ in clayey soil, respectively. The highest treatment was AS which increased yield over control by about 59 and $70 \%$ for shoot and seed in sandy soil; while were about 51.4 and $64.5 \%$ in clayey soil, respectively. In case of applying organic compounds in combination form, the highest treatment was $\mathrm{AS}+\mathrm{AA}+\mathrm{HA}+\mathrm{LC}$ which recorded yield increase over control by about 64.9 and $76.3 \%$ for shoot and seed in sandy soil; while were about 59.1 and $70.7 \%$ in clay soil, respectively. The lowest combination treatment was HA+LC which increased the yield over control by about 56.5 and $63.1 \%$ for shoot and seed in sandy soil; while were about 51.9 and $65.7 \%$ in clay soil, respectively. The organic compounds can be arranged in ascending for its effectiveness in increasing faba bean yield as: $\mathrm{LC}<\mathrm{HA}<\mathrm{AA}<\mathrm{AS}$ in individual forms; while in combination forms as follow: $\mathrm{LC}+\mathrm{HA}<\mathrm{LC}+\mathrm{HA}+\mathrm{AA}<$ $\mathrm{AS}+\mathrm{AA}+\mathrm{HA}<\mathrm{AS}+\mathrm{AA}+\mathrm{HA}+\mathrm{LC}$. These results proved the fact that organic compounds have a vital role in improving plant growth and productivity. These findings paralleled with Scherf et al. (2010) and Schuster et al. (2010) for LC role in plant; Canellas \& Olivares (2014) and El-Bassiouny et al. (2014) for HA role in plant; Abd El-Samad et al. (2010) and Gioseffi et al., (2012) for AA functions in plant; while antioxidants role in plant was reported by Agatia et al. (2012) and Brunetti et al. (2013).

Table 3 shows the effect of mineral fertilizers effect on shoot and seed yield of faba bean without application of micronutrients. The $\mathrm{N}_{1} \mathrm{P}_{1} \mathrm{~K}_{1}$ treatment increased the yield by about 48.3 and $58.6 \%$ over control for shoot and seed in sandy soil; while were 43.8 and $56.2 \%$ in clayey soil, respectively. The $\mathrm{N}_{2} \mathrm{P}_{2} \mathrm{~K}_{2}$ treatment took the same trend and increased the yield over control by about 59.5 and $70.4 \%$ for shoot and seed in sandy soil; while were about 54.4 and $65.7 \%$ in clayey soil, respectively. Combing micronutrients, the $\mathrm{N}_{1} \mathrm{P}_{1} \mathrm{~K}_{1}$ treatment

Egypt. J. Soil Sci. 56, No. 1 (2016) 
recorded increase over control by about 55.8 and $63.7 \%$ of shoot and seed in sandy soil; while were about 50.4 and $62.7 \%$ in clayey soil, respectively. The $\mathrm{N}_{2} \mathrm{P}_{2} \mathrm{~K}_{2}$ treatment along or with micronutrients increased the yield by about 65.2 and $74.7 \%$ over control for shoot and seed in sandy soil; while were about 58.6 and $69.9 \%$ in clayey soil, respectively.

Micronutrients (Zn, B and Mo) application as foliar achieved increase over control by about 13.6 and $8.0 \%$ for shoot and seed under $\mathrm{N}_{1} \mathrm{P}_{1} \mathrm{~K}_{1}$ treatment; while were about 8.7 and $5.8 \%$ under $\mathrm{N}_{2} \mathrm{P}_{2} \mathrm{~K}_{2}$ treatment in sandy soil, respectively. In clayey soil, micronutrients increased the yield by about 12.9 and $10.4 \%$ over control for shoot and seed under $\mathrm{N}_{1} \mathrm{P}_{1} \mathrm{~K}_{1}$ treatment; while under $\mathrm{N}_{2} \mathrm{P}_{2} \mathrm{~K}_{2}$ treatment were about 7.2 and $6.0 \%$, respectively.

Faba bean response to mineral fertilizers and organic compounds was higher in sandy soil than clayey soil. This is true due to the fact that the fertility status of clay soils is higher than sandy soils (Table 1). The available nutrients and plant nutrient contents, yield components and biochemical compounds increased by application of mineral fertilizers and organic compounds. The results of organic compounds treatments agreed with that obtained by Zuhair \& Mohammed (2010) and Al Dulaimy \& Jumaa (2012). While the mineral fertilizers treatments results agreed with that obtained by Fawy (2010), Hamid et al., (2010) and Jasim \& obaid (2014).

Effect of mineral fertilizers and organic compounds on nutrient contents in faba bean

Tables 4, 5 and 6 show that the interactions between mineral fertilizers and organic compounds in combination forms significantly increased nutrient contents in faba bean. The most effective treatment for nutrient contents was $\mathrm{AS}+\mathrm{AA}+$ $\mathrm{HA}+\mathrm{LC}+\mathrm{N}_{2} \mathrm{P}_{2} \mathrm{~K}_{2}$ with micronutrients when compared with other treatments, while the lowest treatment was $\mathrm{HA}+\mathrm{LC}+\mathrm{N}_{1} \mathrm{P}_{1} \mathrm{~K}_{1}$ without micronutrients.

Applications of organic compounds in combination forms increased macronutrient contents in shoot and seed of faba bean in sandy and clay soils (Tables 4) were in HA + LC treatment; while the highest values were recorded in $\mathrm{AS}+\mathrm{AA}+\mathrm{HA}+\mathrm{LC}$ treatment. The most effective treatment for all nutrient contents in shoot and seed was $\mathrm{AS}+\mathrm{AA}+\mathrm{HA}+\mathrm{LC}+\mathrm{N}_{2} \mathrm{P}_{2} \mathrm{~K}_{2}$ with micronutrients when compared with the other treatments; while the lowest treatment was $\mathrm{HA}+\mathrm{LC}+\mathrm{N}_{1} \mathrm{P}_{1} \mathrm{~K}_{1}$ without micronutrients.

Figures 1,2-4) and Table 4 illustrate the effect of macronutrients fertilizers (NPK) application on nutrient contents in shoot and seed. Macronutrients applications could achieve nutrient content over control by about 65.6 and $40.6 \%$ $\mathrm{N}, 75.6$ and $70 \% \mathrm{P}, 60$ and $52.4 \% \mathrm{~K}$ in sandy soil; while were about 48.5 and $42.0 \% \mathrm{~N}, 78.0$ and $62.2 \% \mathrm{P}, 65.5$ and $40.3 \% \mathrm{~K}$ in the clayey soil. Micronutrients fertilizers (B, Mo and $\mathrm{Zn}$ ) significantly increased nutrient contents in shoot and seed over control by about 7.0 and $13.3 \% \mathrm{~N}, 3.7$ and $1.5 \% \mathrm{P}, 8.8$ and $5.8 \% \mathrm{~K}$ in sandy soil; while were about 8.3 and $11.0 \% \mathrm{~N}, 5.5$ and $9.5 \% \mathrm{P}, 3.6$ and $8.9 \% \mathrm{~K}$ in the clay soil. 
TABLE 3. Effect of studied treatments on faba bean yield in the studied soils during two seasons.

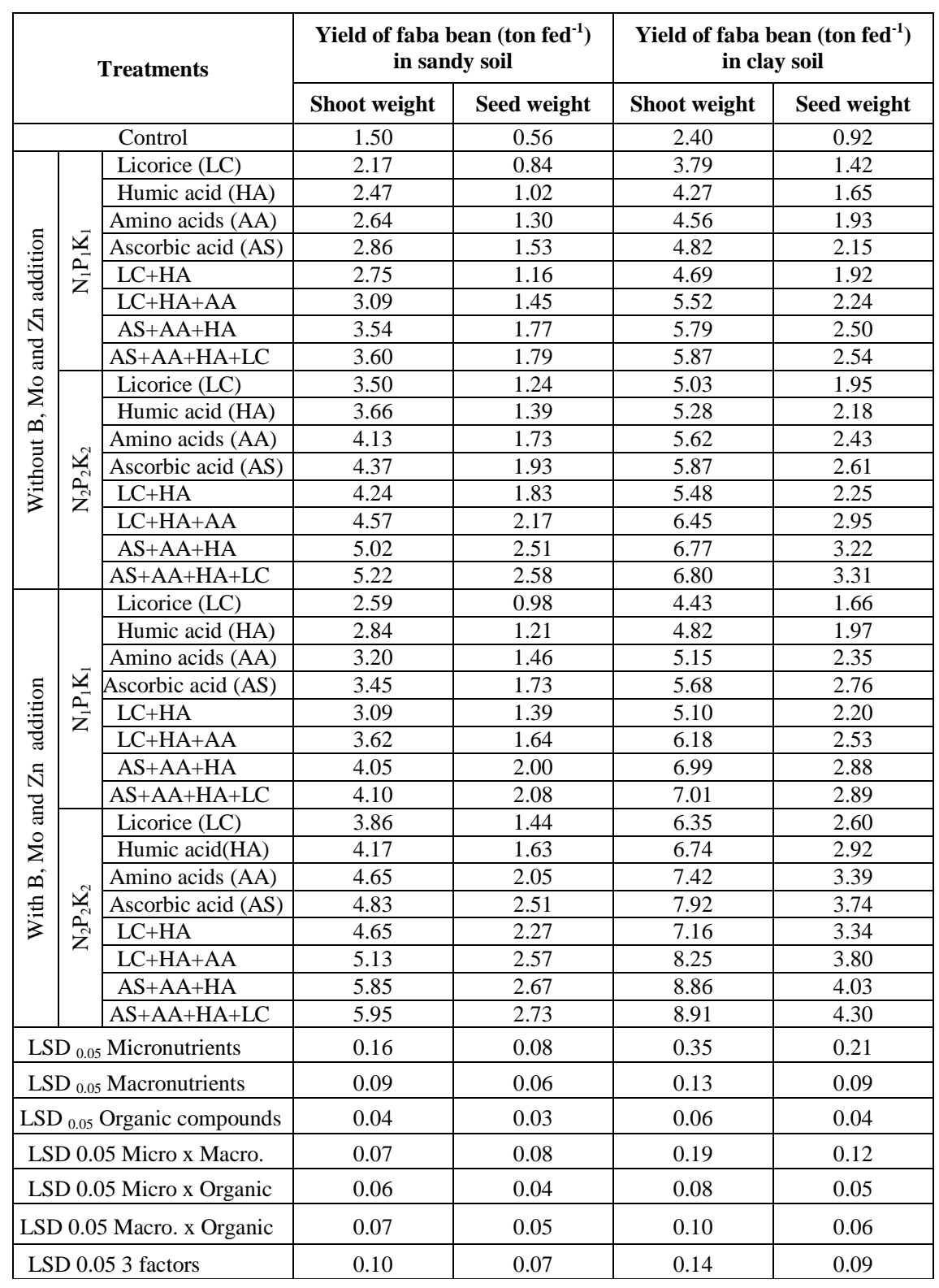

Egypt. J. Soil Sci. 56, No. 1 (2016) 
EFFECT OF MINERAL FERTILIZATION AND SOME ORGANIC COMPOUNDS 77

TABLE 4. Effect of the studied treatments on macronutrient contents of faba bean in the studied soils during two seasons.

\begin{tabular}{|c|c|c|c|c|c|c|c|c|c|c|c|c|c|c|}
\hline \multirow{4}{*}{\multicolumn{3}{|c|}{ Treatments }} & \multicolumn{6}{|c|}{ Nutrients contents in sandy soil } & \multicolumn{6}{|c|}{ Nutrients contents in clay soil } \\
\hline & & & \multicolumn{3}{|c|}{ shoot } & \multicolumn{3}{|c|}{ seeds } & \multicolumn{3}{|c|}{ shoot } & \multicolumn{3}{|c|}{ Seeds } \\
\hline & & & $\mathbf{N}$ & $\mathbf{P}$ & $\mathbf{K}$ & $\mathbf{N}$ & $\mathbf{P}$ & $\mathbf{K}$ & $\mathbf{N}$ & $\mathbf{P}$ & $\mathbf{K}$ & $\mathbf{N}$ & $\mathbf{P}$ & $\mathbf{K}$ \\
\hline & & & & & & $\%$ & & & & & & $\%$ & & \\
\hline \multicolumn{3}{|r|}{ Control } & 0.47 & 0.07 & 0.29 & 0.89 & 0.12 & 0.35 & 0.85 & 0.11 & 0.35 & 1.05 & 0.21 & 0.66 \\
\hline \multirow{8}{*}{ 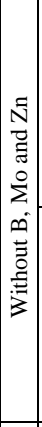 } & \multirow{4}{*}{$\frac{y}{z}$} & $\mathrm{LC}+\mathrm{HA}$ & 0.96 & 0.24 & 0.62 & 1.19 & 0.36 & 0.69 & 1.47 & 0.38 & 0.92 & 1.51 & 0.45 & 0.99 \\
\hline & & $\mathrm{LC}+\mathrm{HA}+\mathrm{AA}$ & 1.32 & 0.27 & 0.65 & 1.64 & 0.4 & 0.76 & 1.52 & 0.41 & 0.95 & 1.65 & 0.48 & 1.09 \\
\hline & & $\mathrm{AS}+\mathrm{AA}+\mathrm{HA}$ & 1.38 & 0.29 & 0.69 & 1.68 & 0.43 & 0.81 & 1.57 & 0.43 & 0.97 & 1.72 & 0.51 & 1.13 \\
\hline & & $\begin{array}{l}\mathrm{AS}+\mathrm{AA}+\mathrm{HA}+ \\
\mathrm{LC}\end{array}$ & 1.41 & 0.31 & 0.71 & 1.71 & 0.45 & 0.84 & 1.59 & 0.45 & 0.98 & 1.77 & 0.53 & 1.16 \\
\hline & \multirow{4}{*}{$\frac{v^{2}}{n^{2}}$} & $\mathrm{LC}+\mathrm{HA}$ & 1.43 & 0.32 & 0.89 & 1.25 & 0.48 & 0.75 & 1.65 & 0.61 & 1.08 & 1.88 & 0.63 & 1.13 \\
\hline & & $\mathrm{LC}+\mathrm{HA}+\mathrm{AA}$ & 1.69 & 0.35 & 0.93 & 1.73 & 0.52 & 0.82 & 1.93 & 0.66 & 1.16 & 2.09 & 0.67 & 1.16 \\
\hline & & $\mathrm{AS}+\mathrm{AA}+\mathrm{HA}$ & 1.74 & 0.38 & 0.95 & 1.75 & 0.57 & 0.89 & 1.98 & 0.68 & 1.18 & 2.13 & 0.69 & 1.19 \\
\hline & & $\begin{array}{l}\mathrm{AS}+\mathrm{AA}+\mathrm{HA}+ \\
\mathrm{LC}\end{array}$ & 1.78 & 0.39 & 0.96 & 1.78 & 0.58 & 0.91 & 2.03 & 0.61 & 1.19 & 2.15 & 0.71 & 1.21 \\
\hline \multirow{8}{*}{ 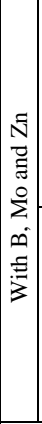 } & \multirow{4}{*}{$\frac{z}{z}$} & $\mathrm{LC}+\mathrm{HA}$ & 1.19 & 0.27 & 0.76 & 1.33 & 0.37 & 0.75 & 1.52 & 0.49 & 1.01 & 1.57 & 0.52 & 1.09 \\
\hline & & $\mathrm{LC}+\mathrm{HA}+\mathrm{AA}$ & 1.52 & 0.31 & 0.79 & 1.84 & 0.42 & 0.82 & 1.73 & 0.53 & 1.04 & 1.83 & 0.57 & 1.16 \\
\hline & & $\mathrm{AS}+\mathrm{AA}+\mathrm{HA}$ & 1.63 & 0.33 & 0.81 & 1.87 & 0.45 & 0.88 & 1.76 & 0.55 & 1.07 & 1.88 & 0.63 & 1.19 \\
\hline & & $\begin{array}{l}\mathrm{AS}+\mathrm{AA}+\mathrm{HA}+ \\
\mathrm{LC}\end{array}$ & 1.65 & 0.34 & 0.82 & 1.89 & 0.46 & 0.91 & 1.79 & 0.58 & 1.09 & 1.92 & 0.66 & 1.21 \\
\hline & \multirow{4}{*}{$\frac{1}{n^{2}}$} & $\mathrm{LC}+\mathrm{HA}$ & 1.52 & 0.35 & 0.96 & 1.34 & 0.49 & 0.81 & 1.73 & 0.68 & 1.17 & 2.05 & 0.71 & 1.21 \\
\hline & & $\mathrm{LC}+\mathrm{HA}+\mathrm{AA}$ & 1.84 & 0.37 & 0.99 & 1.87 & 0.54 & 0.89 & 1.98 & 0.71 & 1.21 & 2.34 & 0.76 & 1.24 \\
\hline & & $\mathrm{AS}+\mathrm{AA}+\mathrm{HA}$ & 1.92 & 0.39 & 1.03 & 1.91 & 0.59 & 0.96 & 2.08 & 0.72 & 1.23 & 2.38 & 0.79 & 1.26 \\
\hline & & $\begin{array}{l}\mathrm{AS}+\mathrm{AA}+\mathrm{HA}+ \\
\mathrm{LC}\end{array}$ & 1.96 & 0.4 & 1.05 & 1.94 & 0.61 & 0.98 & 2.11 & 0.74 & 1.25 & 2.41 & 0.82 & 1.28 \\
\hline \multicolumn{3}{|c|}{$\begin{array}{l}\text { LSD }_{0.05} \text { Micro x } \\
\text { Macro. }\end{array}$} & 0.049 & 0.005 & 0.029 & 0.007 & 0.008 & 0.007 & 0.038 & 0.026 & 0.014 & 0.057 & 0.012 & 0.006 \\
\hline \multicolumn{3}{|c|}{$\begin{array}{l}\text { LSD }_{0.05} \text { Micro x } \\
\text { Organic }\end{array}$} & 0.026 & 0.006 & 0.013 & 0.022 & 0.009 & 0.012 & 0.021 & 0.010 & 0.016 & 0.021 & 0.010 & 0.011 \\
\hline \multicolumn{3}{|c|}{$\begin{array}{l}\text { LSD }_{0.05} \text { Macro. } x \\
\text { Organic }\end{array}$} & 0.032 & 0.007 & 0.016 & 0.027 & 0.010 & 0.014 & 0.026 & 0.013 & 0.020 & 0.026 & 0.012 & 0.014 \\
\hline \multicolumn{3}{|c|}{$\mathrm{LSD}_{0.05} 3$ factors } & 0.045 & 0.010 & 0.023 & 0.029 & 0.011 & 0.020 & 0.036 & 0.018 & 0.028 & 0.036 & 0.012 & 0.020 \\
\hline
\end{tabular}

$\mathrm{LC}=$ Licorice, $\mathrm{HA}=$ Humic acid, $\mathrm{AA}=$ Amino acids and $\mathrm{AS}=$ Ascorbic acid 
TABLE 5. Effect of the studied treatments on micronutrient contents of faba bean in the studied soils during two seasons.

\begin{tabular}{|c|c|c|c|c|c|c|c|c|c|c|c|c|c|c|}
\hline \multirow{3}{*}{\multicolumn{3}{|c|}{ Treatments }} & \multicolumn{6}{|c|}{$\begin{array}{c}\text { Micronutrients of shoot in } \\
\text { sandy soil }\end{array}$} & \multicolumn{6}{|c|}{$\begin{array}{l}\text { Micronutrients of seeds in } \\
\text { clay soil }\end{array}$} \\
\hline & & & $\mathbf{Z n}$ & B & Mo & $\mathbf{F e}$ & Mn & $\mathrm{Cu}$ & $\mathbf{Z n}$ & B & Mo & $\mathbf{F e}$ & Mn & $\mathrm{Cu}$ \\
\hline & & & \multicolumn{6}{|c|}{$\mathrm{mg} \mathrm{kg}^{-1}$} & \multicolumn{6}{|c|}{$\mathrm{mg} \mathrm{kg}^{-1}$} \\
\hline \multicolumn{3}{|c|}{ Control } & 2.24 & 7.4 & 0.42 & 213 & 125 & 1.35 & 3.16 & 8.9 & 0.54 & 236 & 129 & 1.41 \\
\hline \multirow{8}{*}{ 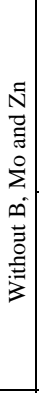 } & \multirow{4}{*}{$\frac{\bar{y}}{2}$} & $\mathrm{LC}+\mathrm{HA}$ & 4.3 & 13.7 & 0.81 & 201 & 108 & 1.72 & 5.29 & 15.9 & 1.02 & 215 & 115 & 1.86 \\
\hline & & $\mathrm{LC}+\mathrm{HA}+\mathrm{AA}$ & 4.43 & 14.2 & 0.83 & 200 & 105 & 1.76 & 5.43 & 16.1 & 1.04 & 209 & 114 & 1.91 \\
\hline & & $\mathrm{AS}+\mathrm{AA}+\mathrm{HA}$ & 4.6 & 14.6 & 0.85 & 198 & 100 & 1.79 & 5.7 & 16.4 & 1.07 & 204 & 111 & 1.94 \\
\hline & & $\begin{array}{l}\mathrm{AS}+\mathrm{AA}+\mathrm{HA}+ \\
\mathrm{LC}\end{array}$ & 4.66 & 15.1 & 0.87 & 196 & 97 & 1.98 & 5.79 & 16.7 & 1.09 & 177 & 109 & 1.98 \\
\hline & \multirow{4}{*}{$\begin{array}{l}v^{2} \\
2^{2} \\
z^{2}\end{array}$} & $\mathrm{LC}+\mathrm{HA}$ & 4.71 & 15.9 & 0.83 & 197 & 103 & 1.76 & 5.71 & 18.1 & 1.04 & 206 & 112 & 1.91 \\
\hline & & $\mathrm{LC}+\mathrm{HA}+\mathrm{AA}$ & 4.91 & 16.4 & 0.86 & 195 & 99 & 1.82 & 5.86 & 18.5 & 1.08 & 203 & 110 & 1.96 \\
\hline & & $\mathrm{AS}+\mathrm{AA}+\mathrm{HA}$ & 5.15 & 16.8 & 0.89 & 193 & 97 & 1.87 & 5.98 & 18.7 & 1.12 & 201 & 109 & 1.99 \\
\hline & & $\begin{array}{l}\mathrm{AS}+\mathrm{AA}+\mathrm{HA}+ \\
\mathrm{LC}\end{array}$ & 5.2 & 17.2 & 0.92 & 190 & 94 & 1.89 & 6.04 & 19 & 1.16 & 196 & 107 & 2.03 \\
\hline \multirow{8}{*}{ 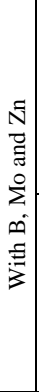 } & \multirow{4}{*}{$\begin{array}{l}\frac{z}{2} \\
\frac{2}{z}\end{array}$} & $\mathrm{LC}+\mathrm{HA}$ & 50.4 & 44.5 & 1.22 & 148 & 80 & 1.76 & 61.8 & 52.8 & 1.58 & 157 & 83 & 1.97 \\
\hline & & $\mathrm{LC}+\mathrm{HA}+\mathrm{AA}$ & 52.8 & 45.3 & 1.26 & 146 & 78 & 1.8 & 64.7 & 53.4 & 1.62 & 155 & 83 & 2.03 \\
\hline & & $\mathrm{AS}+\mathrm{AA}+\mathrm{HA}$ & 55.3 & 45.9 & 1.29 & 143 & 74 & 1.85 & 67.7 & 53.9 & 1.67 & 153 & 81 & 2.08 \\
\hline & & $\begin{array}{l}\mathrm{AS}+\mathrm{AA}+\mathrm{HA}+ \\
\mathrm{LC}\end{array}$ & 57 & 46.5 & 1.32 & 142 & 72 & 1.88 & 70.2 & 54.6 & 1.71 & 150 & 79 & 2.12 \\
\hline & \multirow{4}{*}{$\begin{array}{l}2 \\
n^{2} \\
z^{2}\end{array}$} & $\mathrm{LC}+\mathrm{HA}$ & 54.1 & 46.8 & 1.28 & 143 & 72 & 1.8 & 63.4 & 55.9 & 1.66 & 149 & 78 & 2.03 \\
\hline & & $\mathrm{LC}+\mathrm{HA}+\mathrm{AA}$ & 56.4 & 47.5 & 1.31 & 142 & 71 & 1.85 & 66.3 & 60.6 & 1.69 & 147 & 77 & 2.08 \\
\hline & & $\mathrm{AS}+\mathrm{AA}+\mathrm{HA}$ & 58.1 & 48.1 & 1.36 & 140 & 68 & 1.91 & 69.1 & 61.5 & 1.74 & 145 & 75 & 2.14 \\
\hline & & $\begin{array}{l}\mathrm{AS}+\mathrm{AA}+\mathrm{HA}+ \\
\mathrm{LC}\end{array}$ & 59.4 & 48.8 & 1.39 & 138 & 65 & 1.94 & 71.2 & 62.4 & 1.78 & 143 & 74 & 2.18 \\
\hline \multicolumn{3}{|c|}{$\begin{array}{l}\text { LSD }_{0.05} \text { Micro x } \\
\text { Macro. }\end{array}$} & 0.29 & 0.30 & 0.007 & 0.59 & 0.80 & 0.007 & 0.19 & 0.46 & 0.008 & 0.9 & 0.3 & 0.004 \\
\hline \multicolumn{3}{|c|}{$\begin{array}{l}\text { LSD }_{0.05} \text { Micro X } \\
\text { Organic }\end{array}$} & 0.79 & 0.60 & 0.015 & 1.09 & 0.91 & 0.011 & 0.95 & 0.73 & 0.019 & 1.5 & 0.8 & 0.013 \\
\hline \multicolumn{3}{|c|}{$\begin{array}{l}\text { LSD }_{0.05} \text { Macro. } \mathrm{x} \\
\text { Organic } \\
\end{array}$} & 0.89 & 0.74 & 0.018 & 1.33 & 1.12 & 0.014 & 1.06 & 0.89 & 0.023 & 1.8 & 1.0 & 0.016 \\
\hline \multicolumn{3}{|c|}{$\mathrm{LSD}_{0.05} 3$ factors } & 1.03 & 0.78 & 0.019 & 1.41 & 1.18 & 0.020 & 1.23 & 1.26 & 0.033 & 2.5 & 1.4 & 0.017 \\
\hline
\end{tabular}

$\mathrm{LC}=$ Licorice, $\mathrm{HA}=$ Humic acid, $\mathrm{AA}=$ Amino acids and $\mathrm{AS}=$ Ascorbic acid

The organic compounds as individual forms increased macronutrient contents in shoot and seed over control by about 61 and $32 \% \mathrm{~N}, 72$ and $66 \% \mathrm{P}, 54$ and $44 \% \mathrm{~K}$ in sandy soil; while were about 45 and $39 \% \mathrm{~N}, 77$ and $59 \% \mathrm{P}, 63$ and $37 \% \mathrm{~K}$ in the clay soil. The highest values of $\mathrm{N}, \mathrm{P}$ and $\mathrm{K}$ contents were recorded by AA, HA and AS applications, respectively; while the lowest values were in LC treatment. This could be due to the important role of organic compounds in plant as a growth regulator plant, nutrients sources, protecting the plant from diseases (Schuster et al., 2010), Gioseffi et al., 2012), Brunetti et al., 2013) and El-Bassiouny et al., 2014).

Egypt. J. Soil Sci. 56, No. 1 (2016) 
Data in Tables 5 and 6 and Fig. 5-8 show that mineral fertilizers significantly increased of micronutrient contents in shoot and seed, except $\mathrm{Fe}$ and $\mathrm{Mn}$ contents. the values of $\mathrm{Fe}$ and $\mathrm{Mn}$ contents were decreased to a percentage about 26.3 and $32.8 \% \mathrm{Fe}$ and 39.5 and $34.7 \% \mathrm{Mn}$ in sandy soil; while were 31.3 and $32.9 \% \mathrm{Fe}$ and 43.3 and $50.9 \% \mathrm{Mn}$ in clayey soil compared with control when $\mathrm{N}$, $\mathrm{P}$ and $\mathrm{K}$ fertilizers were applied. Micronutrients fertilizers (B, Mo and $\mathrm{Zn}$ ) applications also reduced $\mathrm{Fe}$ and $\mathrm{Mn}$ contents in shoot and seed compared to control to a percentage about 39.1 and $40.8 \%$ Fe and $45.1 \%$ and $45 \mathrm{Mn}$ in sandy soil; while were 43.6 and $46.1 \% \mathrm{Fe}$ and 58.6 and $66.0 \% \mathrm{Mn}$ in clayey soil. It appears that mineral fertilization reduced the negative impact of high levels of Fe and $\mathrm{Mn}$ on faba bean. This could be due to the antagonistic interaction between $\mathrm{P}$ and $\mathrm{Zn}$ from one side and $\mathrm{Fe}$ and $\mathrm{Mn}$ in the other side. These results are agreeable with Handreck (2006) who reported that the high $\mathrm{P}$ additions reduced accumulation of $\mathrm{Fe}$ into leaves, while the high rate of $\mathrm{Fe}$ additions reduced accumulation of $\mathrm{P}$ in the leaves.

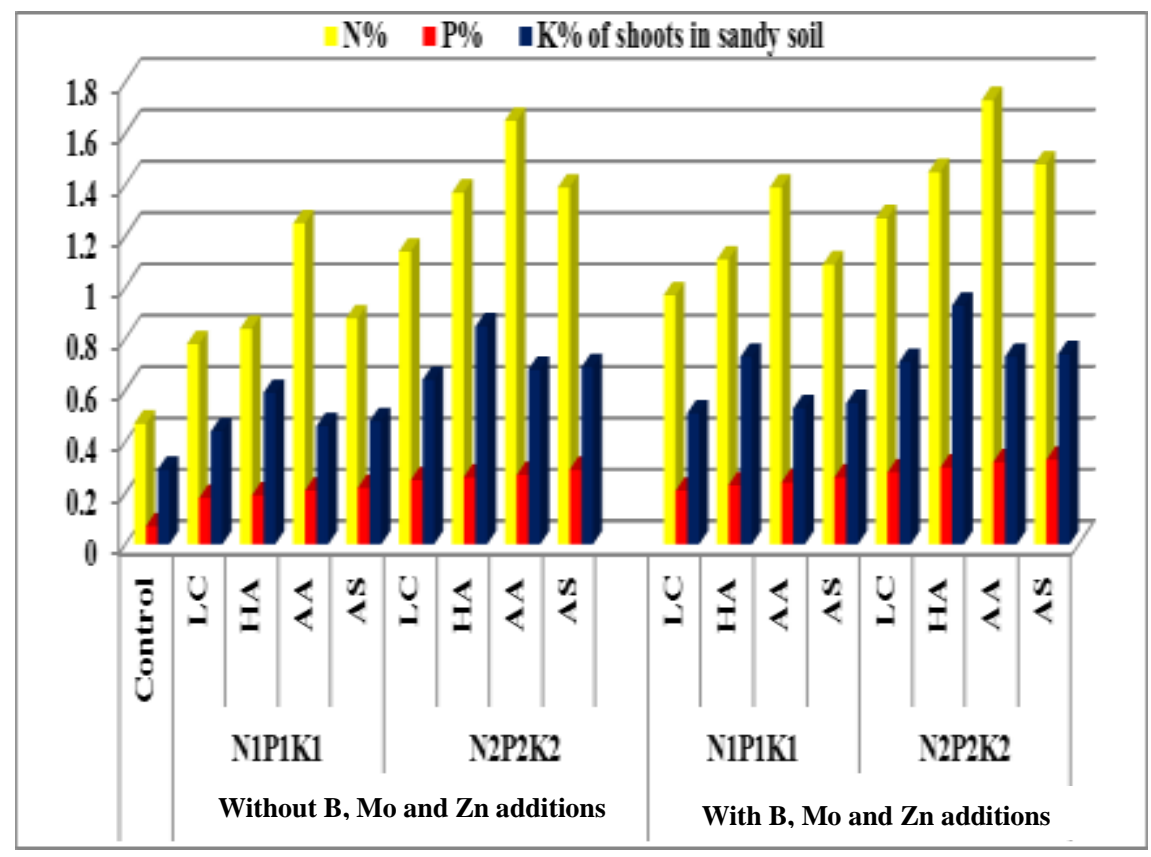

Fig. 1. Effect of studied treatment on macronutrient contents in faba bean shoot in sandy soil. 


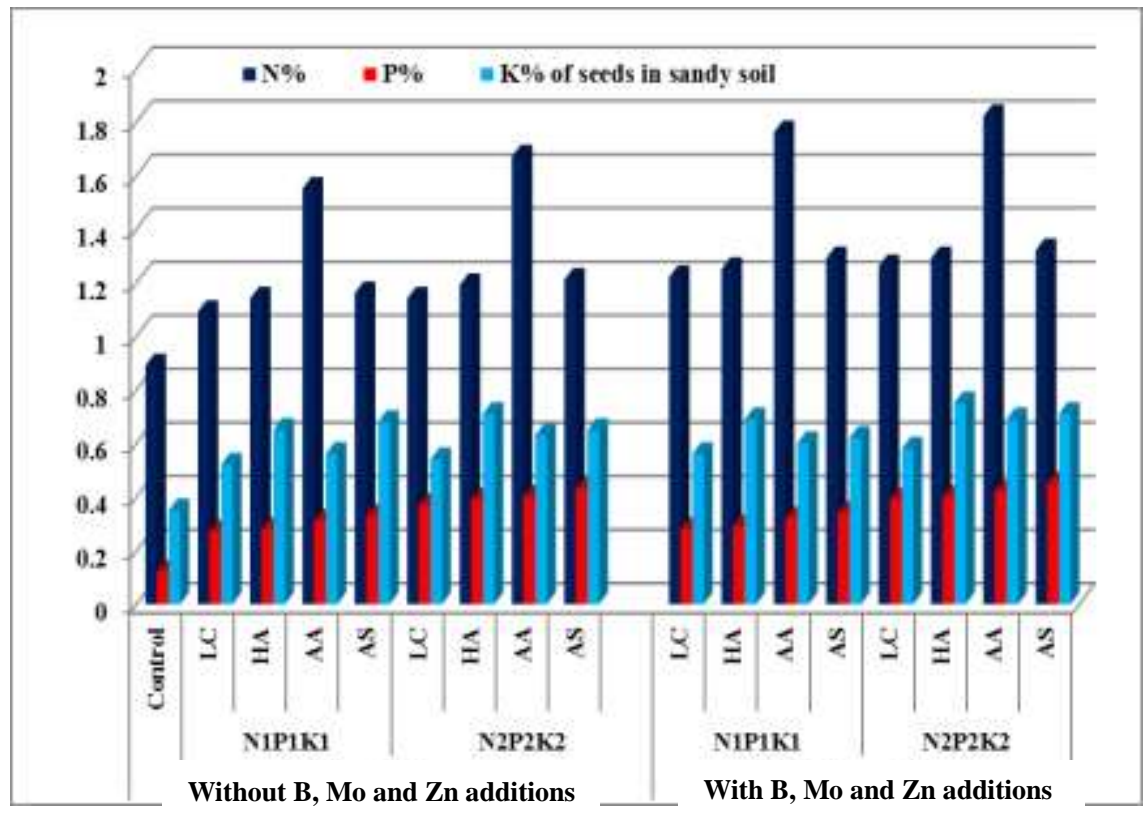

Fig. 2. Effect of studied treatments on macronutrient contents in faba bean seed in sandy soil.

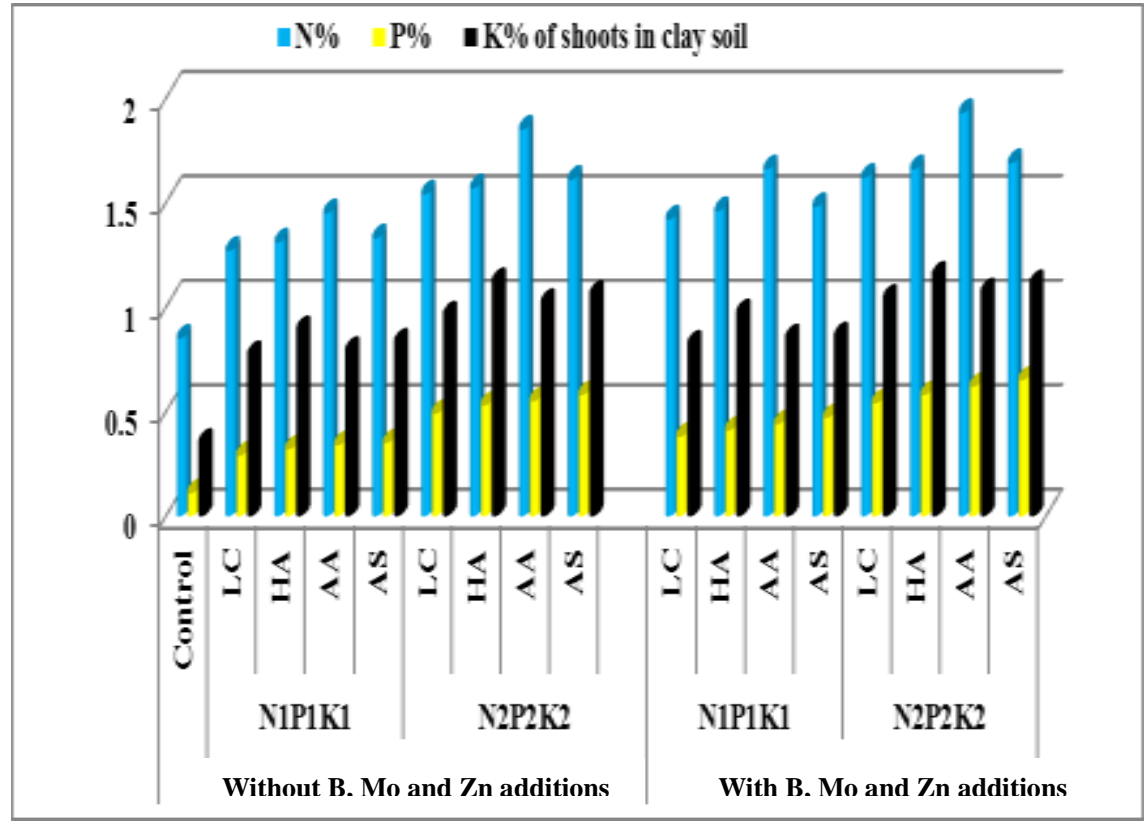

Fig.3. Effect of studied treatments on macronutrient contents in faba bean shoot in clay soil.

Egypt. J. Soil Sci. 56, No. 1 (2016) 


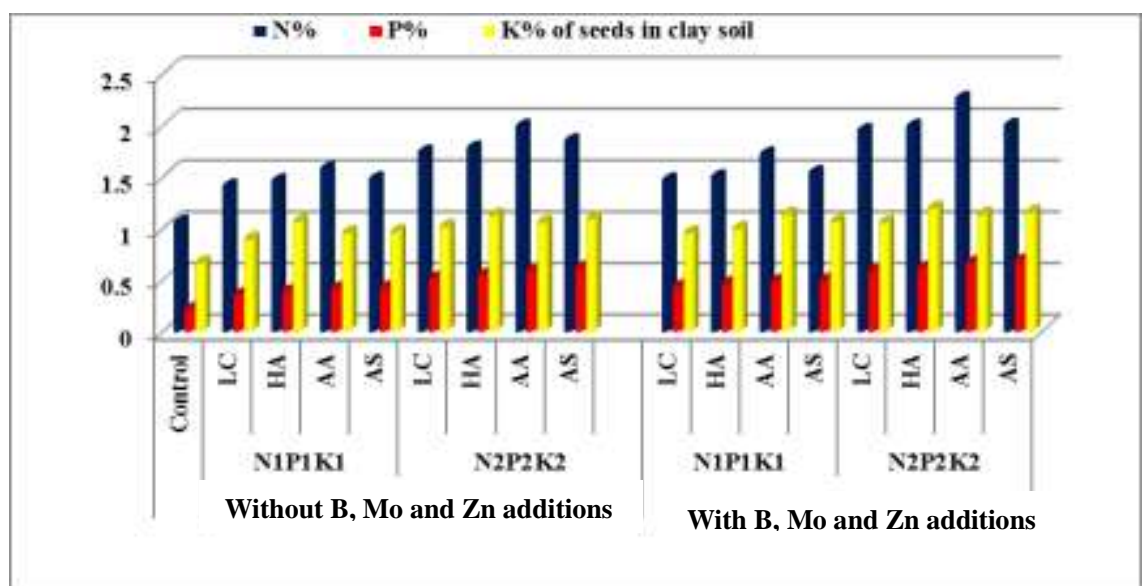

Fig.4. Effect of studied treatments on macronutrient contents in faba bean seed in clay soil.

TABLE 6. Effect of the interaction between mineral fertilizers and some organic compounds on micronutrient contents in faba bean in clay soil during two seasons.

\begin{tabular}{|c|c|c|c|c|c|c|c|c|c|c|c|c|c|}
\hline \multirow{3}{*}{\multicolumn{2}{|c|}{ Treatments }} & \multicolumn{6}{|c|}{ Micronutrients in shoot } & \multicolumn{6}{|c|}{ Micronutrients in seeds } \\
\hline & & $\mathbf{Z n}$ & B & Mo & $\mathbf{F e}$ & Mn & $\mathbf{C u}$ & $\mathbf{Z n}$ & B & Mo & $\mathbf{F e}$ & Mn & $\mathbf{C u}$ \\
\hline & & \multicolumn{6}{|c|}{$\mathrm{mg} \mathrm{kg}^{-1}$} & \multicolumn{6}{|c|}{$\mathrm{mg} \mathrm{kg}^{-1}$} \\
\hline & Control & 4.21 & 11.6 & 0.93 & 286 & 3 & 2.14 & 6.58 & 15.3 & 1.08 & 314 & 174 & 2.37 \\
\hline \multirow{8}{*}{ 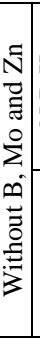 } & $\mathrm{LC}+\mathrm{HA}$ & 6.71 & 18.1 & 1.31 & 267 & 35 & 2.59 & 8.6 & 22.5 & 1.65 & 298 & 155 & 2.81 \\
\hline & $\asymp \mathrm{LC}+\mathrm{HA}+\mathrm{AA}$ & 76 & 18.5 & 1.35 & 261 & 131 & 2.63 & 8.64 & 22.9 & 1.69 & 295 & 51 & 2.85 \\
\hline & $=A S+A A+H A$ & 6.81 & 18.8 & 1.38 & 257 & 127 & 2.65 & 8.68 & 23.3 & 1.73 & 292 & 147 & 2.9 \\
\hline & $\begin{array}{l}\mathrm{AS}+\mathrm{AA}+\mathrm{HA} \\
+\mathrm{LC}\end{array}$ & 6.85 & 19.2 & 1.42 & 249 & 123 & 2.68 & 8.71 & 24.1 & 1.78 & 290 & 145 & 2.93 \\
\hline & $\mathrm{LC}+\mathrm{HA}$ & 6.85 & 18.7 & 36 & 253 & 130 & 2.62 & 8.61 & 24.6 & 1.74 & 271 & 138 & 2.92 \\
\hline & $\approx \overline{L C+}$ & 6.9 & 19.1 & 1.38 & 249 & 127 & 2.66 & 8.66 & 25 & 1.78 & 269 & 135 & 2.96 \\
\hline & $\mathrm{AS}+1$ & 6.94 & 19.4 & 1.42 & 244 & 123 & 2.69 & 8.7 & 25.2 & 1.82 & 267 & 131 & 3 \\
\hline & $\begin{array}{ll}\mathrm{z} & \begin{array}{l}\mathrm{AS}+\mathrm{AA}+1 \\
+\mathrm{LC}\end{array} \\
\end{array}$ & 6.99 & 19.9 & 1.46 & 239 & 120 & 2.73 & 8.74 & 25.7 & 1.86 & 265 & 127 & 3.03 \\
\hline \multirow{8}{*}{$\begin{array}{l}\mathbf{N} \\
0 \\
\vdots \\
0 \\
\Sigma \\
n \\
\vdots \\
\vdots \\
3\end{array}$} & $\mathrm{LC}+1$ & 7.6 & 65.2 & 17 & 197 & 0 & 79 & 97.7 & 9.5 & .66 & 209 & 95 & 2.88 \\
\hline & $\simeq \mathrm{LC}+$ & .8 & 5.8 & 1 & 193 & 6 & 83 & 100.5 & 80.2 & 2.69 & 206 & 94 & 2.92 \\
\hline & $=\mathrm{AS}+$ & 81.9 & 66.5 & 2.25 & 191 & 83 & 2.86 & 103 & 80.9 & 2.74 & 202 & 91 & 2.97 \\
\hline & $\begin{array}{l}\mathrm{AS}+\mathrm{AA}+\mathrm{HA} \\
+\mathrm{LC}\end{array}$ & 83.8 & 67.1 & 2.28 & 186 & 79 & 2.89 & 105.5 & 81.6 & 2.77 & 201 & 88 & 3 \\
\hline & $\mathrm{LC}+\mathrm{HA}$ & 82.2 & 67.8 & 2.32 & 183 & 85 & 2.91 & 3.6 & 83.2 & 2.71 & 193 & 90 & 3.08 \\
\hline & $\therefore \mathrm{LC}+\mathrm{HA}+\mathrm{AA}$ & .3 & 68.5 & 2.36 & 179 & 2 & 2.95 & 106.1 & 83.9 & 2.76 & 188 & 88 & 3.11 \\
\hline & AS+A & 86.7 & 69.2 & 2.39 & 175 & 79 & 2.97 & 108.4 & 84.6 & 2.79 & 185 & 86 & 3.14 \\
\hline & $\begin{array}{l}\mathrm{AS}+\mathrm{AA}+\mathrm{HA} \\
+\mathrm{LC}\end{array}$ & 6 & .8 & 2.44 & 170 & 77 & 9 & 110.1 & .2 & .84 & 183 & 83 & 3.19 \\
\hline \multicolumn{2}{|c|}{$\begin{array}{l}\mathrm{LSD}_{0.05} \text { Micro x } \\
\text { Macro. }\end{array}$} & & & & & & 12 & 8 & 39 & .009 & 90 & 1.57 & .020 \\
\hline \multicolumn{2}{|c|}{$\begin{array}{l}\text { LSD }_{0.05} \text { Micro x } \\
\text { Organic }\end{array}$} & & 5 & 222 & .74 & 16 & 0.014 & 1.46 & 1.02 & 0.027 & 1.85 & 1.38 & 0.013 \\
\hline \multicolumn{2}{|c|}{$\begin{array}{l}\text { LSD }_{0.05} \text { Macro. } \mathrm{x} \\
\text { Organic }\end{array}$} & 1.32 & 0.95 & 27 & 2.13 & 1.42 & 0.017 & 1.63 & 1.25 & 0.033 & 2.27 & 1.69 & 0.016 \\
\hline \multicolumn{2}{|r|}{$\mathrm{LSD}_{0.05} 3$ factors } & 1.52 & 1.10 & 0.038 & 3.02 & 1.50 & 0.024 & 1.89 & 1.32 & 0.035 & 3.20 & 2.40 & 0.023 \\
\hline
\end{tabular}

Egypt. J. Soil Sci. 56, No.1 (2016) 
Organic compounds applications in combination forms as shown in Tables 5 and 6 increased micronutrient contents in shoot and seed, expect $\mathrm{Fe}$ and $\mathrm{Mn}$ where their concentrations were decreased with organic compounds applications. The most efficient treatment about the increase micronutrient contents in shoot and seed was $\mathrm{AS}+\mathrm{AA}+\mathrm{HA}+\mathrm{LC}+\mathrm{N}_{2} \mathrm{P}_{2} \mathrm{~K}_{2}$ with micronutrients. The organic compounds in individual forms (Fig. 5-8) reduced Fe and Mn contents in shoot and seed compared with control to a percentage about 20.9 and $25.2 \% \mathrm{Fe}$ and 28.0 and $26.1 \% \mathrm{Mn}$ in sandy soil; while were 24.5 and $25.8 \% \mathrm{Fe}$ and 29.6 and $36.6 \% \mathrm{Mn}$ in clayey soil. The highest values reduction in $\mathrm{Fe}$ and $\mathrm{Mn}$ were observed in AS treatment; while the lowest values were in LC treatment. These observations have been noted by Wandruszka (2006), Handreck (2006), Fawy (2010), Bozorgi et al. (2011) and Jasim \& obaid (2014).

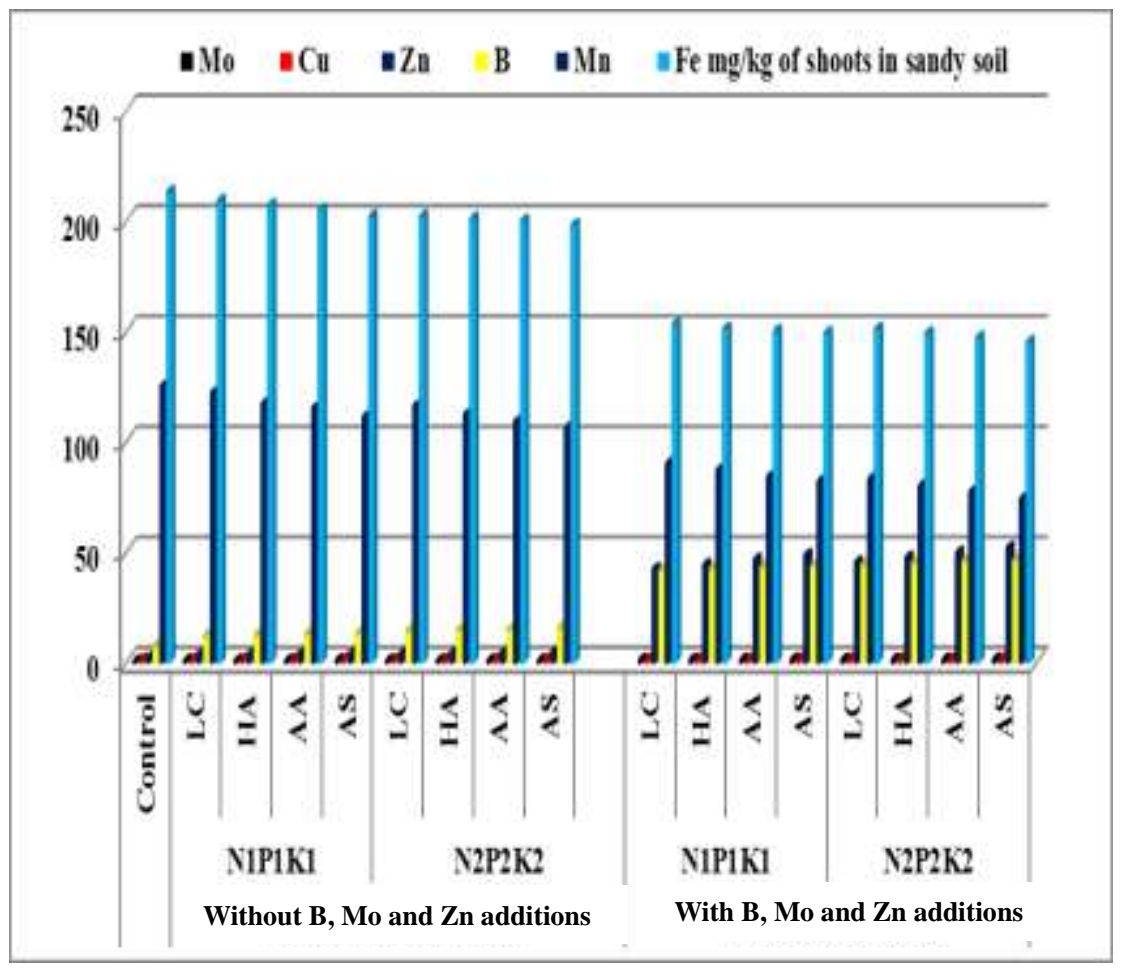

Fig. 5. Effect of studied treatments on micronutrient contents in faba bean shoot in sandy soil. 


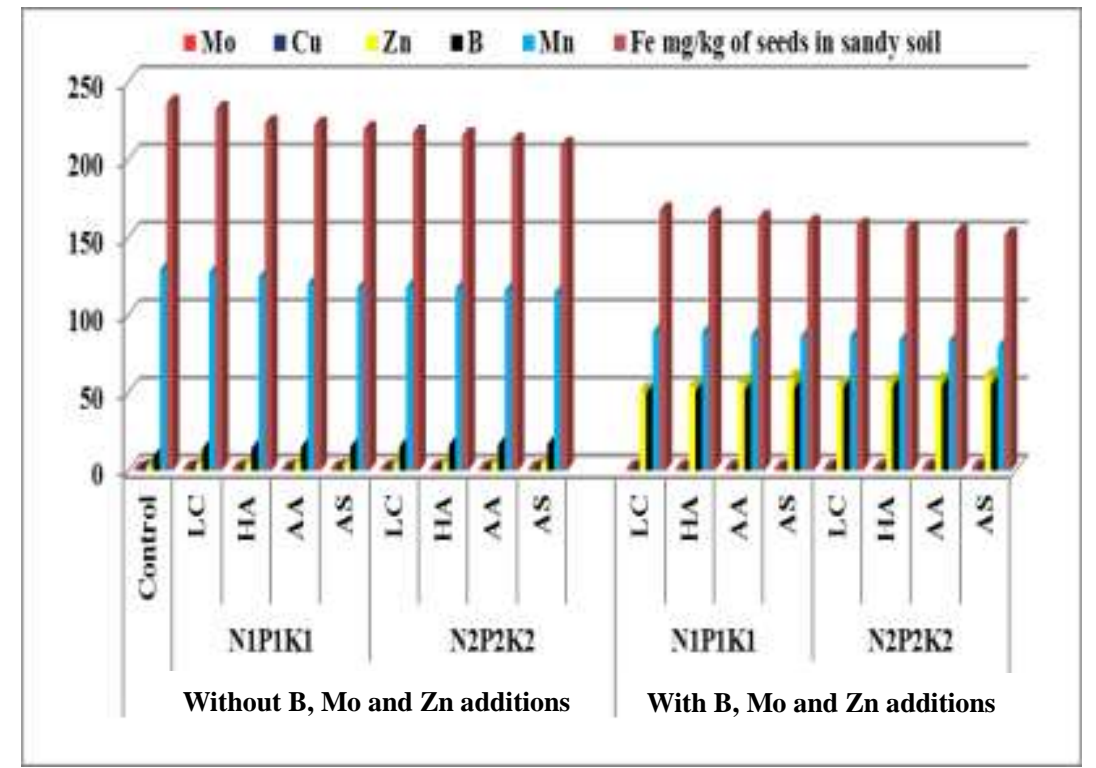

Fig.6. Effect of studied treatments on micronutrient contents in faba bean seed in sandy soil.

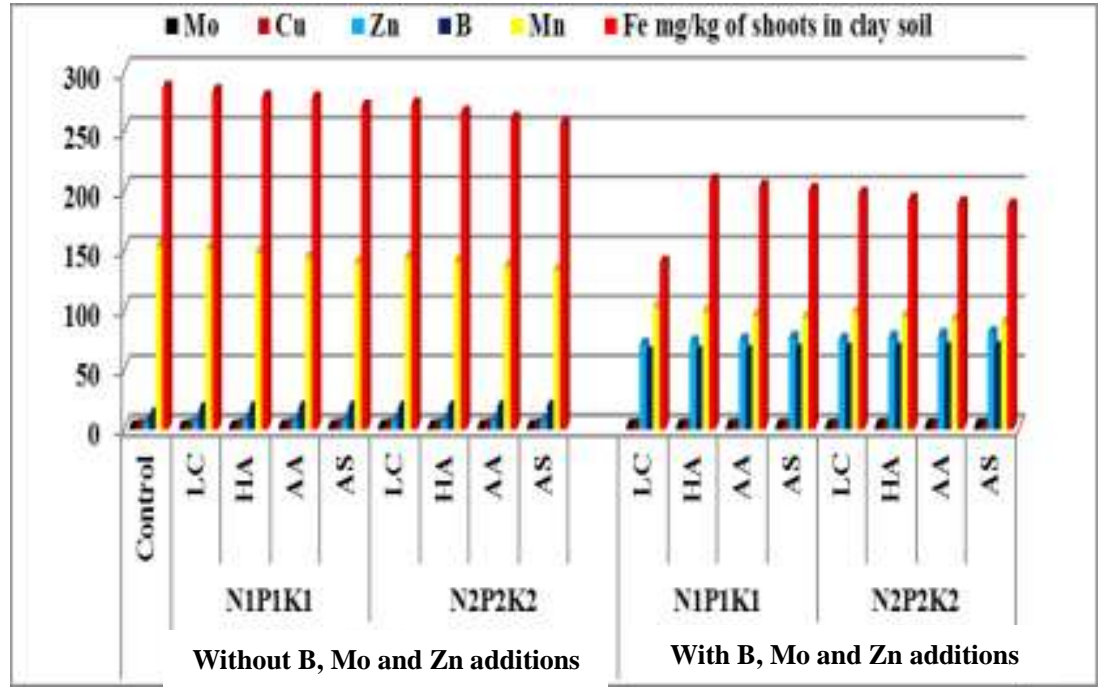

Fig. 7. Effect of mineral fertilizers and some organic compounds on macronutrient contents of faba bean shoot in clay soil. 


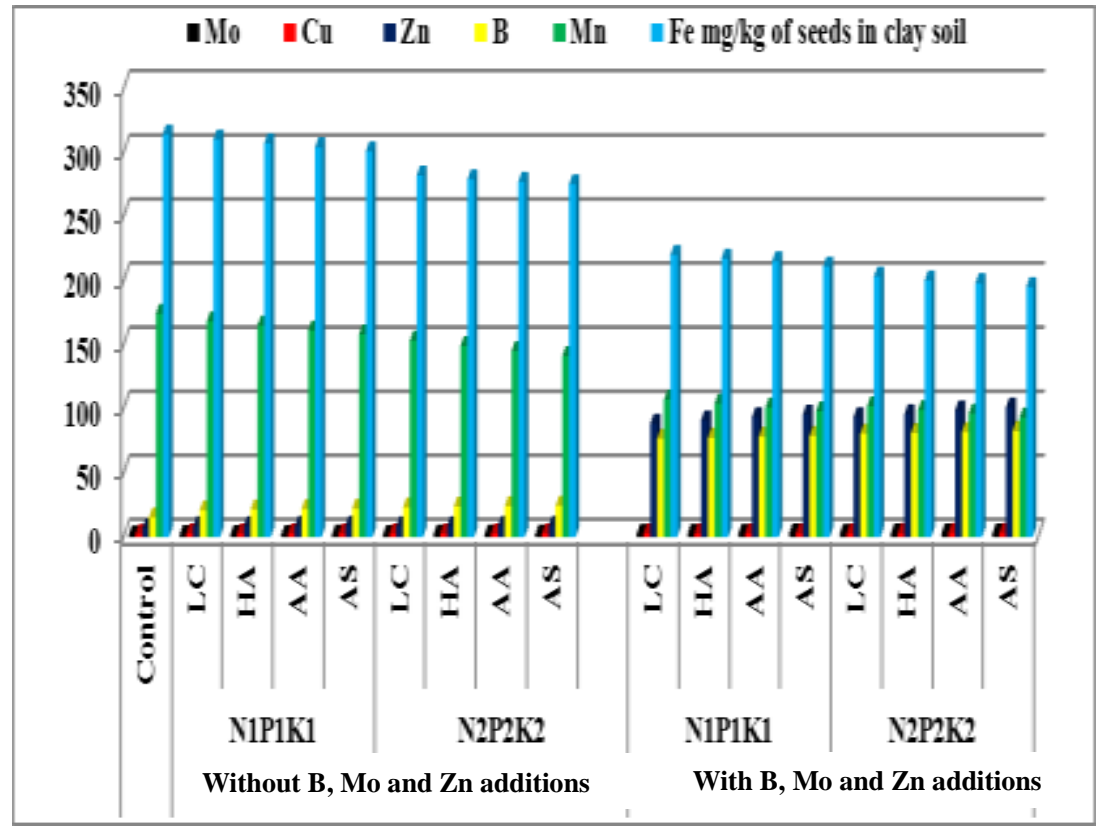

Fig. 8. Effect of mineral fertilizers and some organic compounds on macronutrient contents in faba bean seed in clay soil.

Effect of mineral fertilizers and some organic compounds on total phenols and antioxidants

As shown in Table 7, application of mineral fertilizers especially micronutrients significantly increased total phenols and total antioxidants activities in shoot and seed of faba bean. This has been reported by Hamid et al. (2010), Gill \& Tuteja (2010), Agatia et al. (2012), and Brunetti et al. (2013).

The best treatment for total phenol and total antioxidant activities in shoot and seed were $\mathrm{AS}+\mathrm{AA}+\mathrm{HA}+\mathrm{LC}+\mathrm{N}_{2} \mathrm{P}_{2} \mathrm{~K}_{2}+$ with micronutrients which achieved 216 and $227 \mu \mathrm{g}$ Ascorbic acid ml ${ }^{-1}$ extract of total antioxidants and 791 and $876 \mu \mathrm{mol}$ of Gallic acid $\mathrm{ml}^{-1}$ extract total phenols for shoot and seed, respectively in sandy soil; while were 231 and $243 \mu \mathrm{g}$ Ascorbic acid ml ${ }^{-1}$ extract of total antioxidants and 891 and $983 \mu \mathrm{mol}$ of Gallic acid $\mathrm{ml}^{-1}$ extract of total phenols in clayey soil, respectively. The AS and LC treatments had higher values of total phenols and antioxidants contents than HA and AA treatmen. 
EFFECT OF MINERAL FERTILIZATION AND SOME ORGANIC COMPOUNDS 85

TABLE 7. Effect of mineral fertilizers and some organic compounds on biochemical contents in faba bean in the studied soils during two seasons.

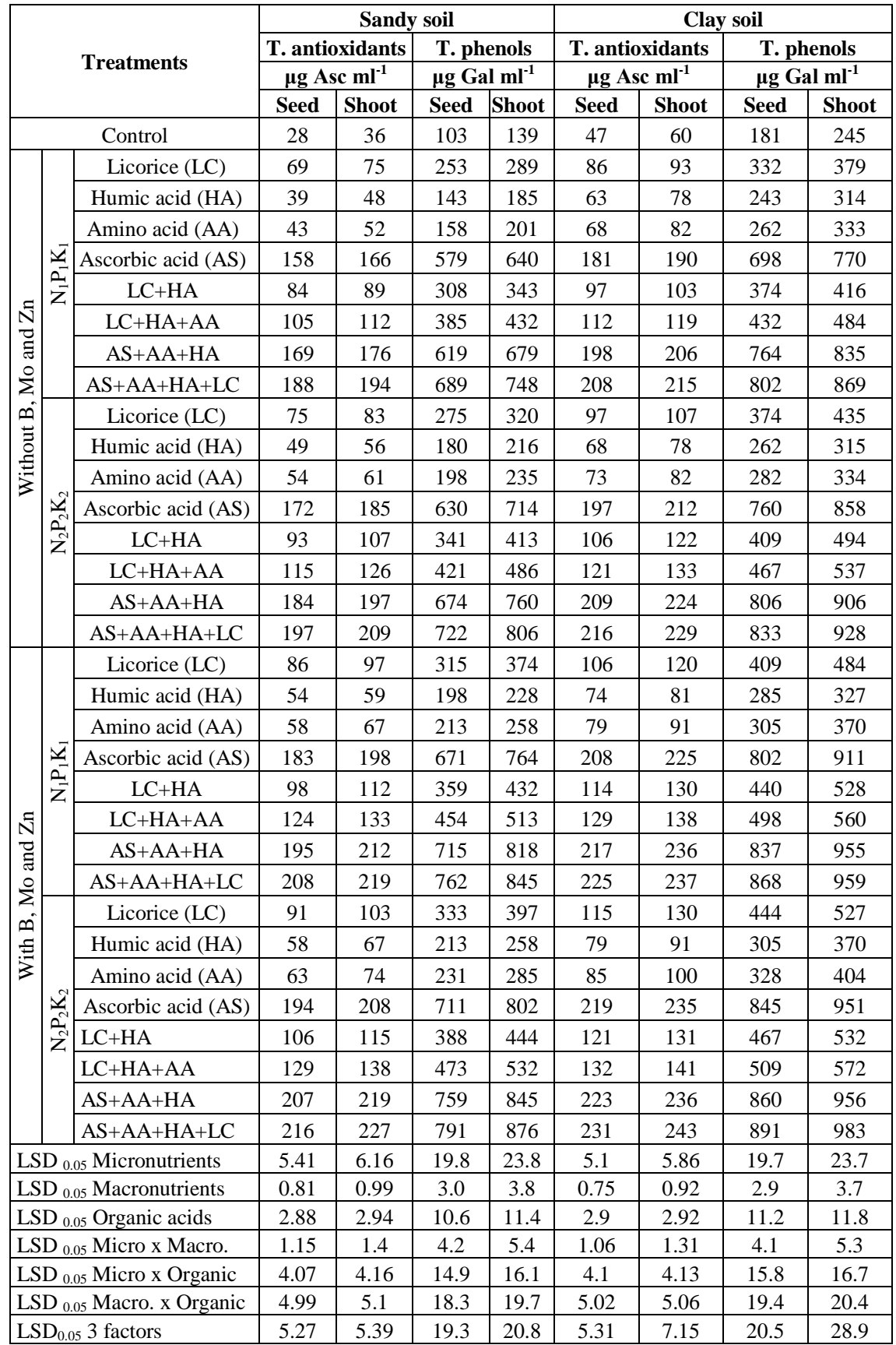

Total Antioxidants $\mu \mathrm{g}$ of Ascorbic acid/ml extract, Total phenol $\mu \mathrm{mol}$ of Gallic acid $/ \mathrm{ml}$ extract .

Egypt. J. Soil Sci. 56, No.1 (2016) 


\section{Conclusions}

Application of mineral fertilizers and some organic compounds increased yield components, nutrient contents, total antioxidants activity and total phenols in faba bean. The lowest values of faba bean yield were in LC treatment; while the highest values obtained in AS treatment. The organic compounds could be arranged in ascending order as: $\mathrm{LC}<\mathrm{HA}<\mathrm{AA}<\mathrm{AS}$. The integration between the organic compounds had higher values than individual applications and could be arranged in ascending order as: $\mathrm{LC}+\mathrm{HA}<\mathrm{LC}+\mathrm{HA}+\mathrm{AA}<\mathrm{AS}+\mathrm{AA}+\mathrm{HA}<$ $\mathrm{AS}+\mathrm{AA}+\mathrm{HA}+\mathrm{LC}$. Application of $\mathrm{N}, \mathrm{P}$ and $\mathrm{K}$ along with micronutrients (B, Mo and $\mathrm{Zn}$ ) reduced $\mathrm{Fe}$ and $\mathrm{Mn}$ contents in shoot and seed of faba bean and increased other nutrients which reflected positively on faba bean yield and quality. The LC treatment had higher values of total phenols and antioxidants contents than HA and AA treatments; while AS treatment had the highest values. The most effective treatment was $\mathrm{AS}+\mathrm{AA}+\mathrm{HA}+\mathrm{LC}+\mathrm{N}_{2} \mathrm{P}_{2} \mathrm{~K}_{2}$ with micronutrients which recorded 5.95 and $2.73 \mathrm{tfed}^{-1}$ for shoot and seed, respectively in sandy soil; while were 8.91 and $4.30 \mathrm{t} \mathrm{fed}^{-1}$ in clayey soil, respectively. Also this treatment could achiev 216 and $227 \mu \mathrm{g}$ Ascorbic acid $\mathrm{ml}^{-1}$ extract of total antioxidants and 791 and $876 \mu \mathrm{mol}$ of Gallic acid $\mathrm{ml}^{-1}$ extract of total phenols in shoot and seed respectively in sandy soil; while were 231 and $243 \mu \mathrm{g}$ Ascorbic acid $\mathrm{ml}^{-1}$ extract of total antioxidants and 891 and $983 \mu \mathrm{mol}$ of Gallic acid ml ${ }^{-1}$ extract of total phenols in clay soil, respectively.

\section{References}

Abd Al Hamid, M., El Bramawy, S.A. and Shaban, W.I. (2010) Effects of potassium fertilization on agronomic characters and resistance to chocolate spot and rust diseases in faba bean. Tunisian Journal of Plant Protection 5, No. 2, 131-150.

Abd El-Samad, H.M., Shaddad, M.A.K. and Barakat, N. (2010) The role of amino acids in improvement in salt tolerance of crop plants. Journal of Stress Physiology \& Biochemistry, 6 (3), 25-37.

Abdelgawad, Z.A. (2014) Improving Growth and Yield of Salt-stressed Cowpea Plants by Exogenous Application of Ascobin. Life Science Journal 2014;11 (11), 43-51.

Abou EL-Yazied and Mady, M.A. (2012) Effect of boron and yeast extract foliar application on growth, pod setting and both green pod and seed yield of broad bean (Vicia faba L). Journal of American Science, 8 (4),517-533.

Agatia, G., Azzarellob, E., Pollastri, S. and Tattini, M. (2012) Flavonoids as antioxidants in plants: Location and functional significance. Plant Science, 196, 6776.

Al Dulaimy, A.F. and Jumaa, F.F. (2012) Response of Black Hamburg grape cv, (Schiava grossa L. ) to foliar spray with Yeast suspension, Licorice roots extract and Amino Quelant-K compound. Anbar Journal of Agricultural Sciences, 10 (1), 48-65. 
Ali, M.A., Ali, A., Ahmad, M.I., Hassan, S.W., Khan, S.R. and Abid , A.A. (2014) Phosphorus effects on growth and yield parameters of mungbean. Sci. Int. (Lahore) 26 (4),1821-1824.

Amin, A.A., Abouziena, H.F., Abdelhamid, M.T., Rashad, El-Sh. M. and Gharib, A.E.F. (2014) Improving Growth and Productivity of Faba Bean Plants by Foliar Application of Thiourea and Aspartic Acid. International Journal of Plant \& Soil Science 3 (6), 724-736.

Ati, A.S. and Ali, N.S. (2011) The Effect of Boron Fertilization on Faba bean (Vicia faba L) yield, fertilizer and water productivity. Researches of The First International Conference (Babylon and Razi Universities), ISSN 2072-3875: 81-86.

Azooz, M.M., Alzahrani, A.M. and Youssef, M.M. (2013) The potential role of seed priming with ascorbic acid and nicotinamide and their interactions to enhance salt tolerance in broad bean (Vicia faba L.). AJCS, 7 (13), 2091-2100.

Bozorgi, H.R., Azarpour, E. and Moradi, M. (2011) The effects of bio, mineral nitrogen fertilization and foliar zinc spraying on yield and yield components of Faba Bean. World Appl. Sci. J., 13 (6),1409-1414.

Britto, D.T. and Kronzucker, H.J. (2008) Cellular mechanisms of potassium transport in plants. Physiologia Plantarum, ISSN 0031-9317:1-14.

Brunetti, C., Ferdinando, M.D., Fini, A., Pollastri, S. and Tattini, M. (2013) Flavonoids as antioxidants and developmental regulators: relative significance in plants and humans. Int. J. Mol. Sci.,14, 3540-3555.

Canellas, L.P. and Olivares, F.L. (2014) Physiological responses to humic substances as plant growth promoter. Canellas and Olivares Chemical and Biological Technologies in Agriculture, 1(3),1-11.

Cottenie, A., Verlso, M., Kilkens, L., Velghe, G. and Camerlynck, R. (1982) Chemical Analysis of Plants and Soils. Lab. Agroch. State Univ. Gent, Belgium.

Eduardo, C., Adelson, P.A., Bruno, J.R.A. and Teixeira, M.G. (2010) Seeds enriched with phosphorus and molybdenum improve the contribution of biological nitrogen fixation to common bean as estimated by $15 \mathrm{n}$ isotope dilution. R. Bras. Ci. Solo, 34,1093-1101.

El Habbasha, S.F., Hozayn, M. and Khalafallah, M.A. (2007) Integration effect between phosphorus levels and bio-fertilizers on quality and quantity yield of faba bean (vicia faba L.) in newly cultivated sandy soils. Research Journal of Agriculture and Biological Sciences, 3 (6), 966-971.

El-Bassiouny, H.S.M., Bakry, B.A., Attia, A.A. and Abd Allah, M.M. (2014) Physiological role of humic acid and nicotinamide on improving plant growth,yield, and mineral nutrient of wheat (triticum durum) grown under newly reclaimed sandy soil. Agricultural Sciences, 5, 687-700. 
El-Ghamry, A.M., Abd El-Hai, K.M. and Ghoneem, K.M. (2009) Amino and humic acids promote growth, yield and disease resistance of faba bean cultivated in clayey soil. Australian Journal of Basic and Applied Sciences, 3 (2), 731-739.

Fahramand, M., Moradi, H., Noori, M., Sobhkhizi, A., Adibian, M., Abdollahi, V. and Rigi, K. (2014) Influence of humic acid on increase yield of plants and soil properties. International Journal of Farming and Allied Sciences, 3 (3), 339-341.

Fawy, H.A. (2010) Integration effect between soil and foliar of application fertilizers to approach the maximum yields of some Legume crops grown on sandy soil in ElBostan region. J. Appl. Sci., 25 ( 2, 4 ) $33-48$.

Gad El-Hak, S.H., Ahmed, A.M. and Moustafa, Y.M.M. (2012) Effect of foliar application with two antioxidants and humic acid on growth, yield and yield components of peas (Pisum sativum L.). Journal of Horticultural Science \& Ornamental Plants 4 (3), 318-328.

Gill, S.S. and Tuteja, N. (2010) Reactive oxygen species and antioxidant machinery in abiotic stress tolerance in crop plants. Plant Physiology and Biochemistry, 48, 909-930.

Gioseffi, E., Neergaard, A.D. and Schjoerring, J.K. (2012) Interactions between uptake of amino acids and inorganic nitrogen in wheat plants. Biogeosciences, 9, 1509-1518.

Gomez, K.A. and Gomez, A.A. (1984) Statistical Procedures for Agricultural Research. 2nd ed., Wiley, New York.

Hafeez, B., Khanif, Y.M. and Saleem, M. (2013) Role of Zinc in Plant Nutrition- A Review. American Journal of Experimental Agriculture, 3 (2), 374-391.

Hamid, A.A., Aiyelaagbe, O.O., Usman, L.A., Ameen, O.M. and Lawal, A. (2010) Antioxidants: Its medicinal and pharmacological Applications. African Journal of Pure and Applied Chemistry, 4 (8),142-151.

Handreck, K.A. (2006) Interactions Between Iron and Phosphorus in the Nutrition of Banksia ericifolia L.f var ericifolia (Proteaceae) in Soil-Less Potting Media. Australian Journal of Botany, 39 (4) 373 - 384.

Ibraheim, S.K.A. (2014) Effect of foliar spray with some biostimulants on growth, yield and seeds quality of pea plants grown in sandy soil. Journal of Applied Sciences Research,10 (5):400-407. International Journal of Plant \& Soil Science, 3 (6), 724736.

Jasim, A.H. and Obaid , A.S. (2014) Effect of foliar fertilizers spray, boron and their interaction on broad bean (Vicia faba L.) yield. Scientific Papers. Series B, Horticulture. Vol. LVIII, ISSN 2285-5653.

Jasim, A.H. and Mhanna, Q.L. (2014) Effect of some organic fertilizers treatments on dry seed yield of broad bean (Vicia faba L.). Scientific Papers. Series A. Agronomy, Vol. LVII : 218- 222. 
Kandil, H., Gad, N. and Abdelhamid, M.T. (2013) Effects of different rates of phosphorus and molybdenum application on two varieties common bean of (Phaseolus vulgaris L.). J. Agric. Food. Tech., 3 (3), 8-16.

Khaled, H. and Fawy, H.A. (2011) Effect of different levels of humic acids on the nutrient content, plant growth, and soil properties under conditions of salinity. Soil and Water Res., 6, 2011 (1), 21-29.

Klute, A.A. (1986) Methods of Soil Analysis. Part $12^{\text {nd }}$ ed. American Society of Agronomy. Inc. Publishes, Madison, Wisconsin, USA.

Ortiz-Lopez, A., Chang, H.C. and Bush, D.R. (2000) Amino acid transporters in plants. Biochimica et Biophysica Acta, 1465, 275-280.

Page, A.L., Miller, R.H. and Keeney, D.R. (1984) Methods of Soil Analysis. part 2: Chemical and Microbiological Properties. Second edition. Agronomy J. 9: 2, Am. Soc. Agron. Inc., Soil Sci. Soc. Am. Inc. Pub. Madison, Wisconsin, USA.

Rimmer, S. (2009) Antioxidants in soil organic matter and in associated plant materials. European Journal of Soil Science, 60 (2),170-175.

Sadak, M. Sh., Dawood, M.G., Bakry, B.A. and El-Karamany, M.F. (2013) Synergistic effect of indole acetic acid and kinetin on performance, some biochemical constituents and yield of faba bean plant grown under newly reclaimed sandy soil. World Journal of Agricultural Sciences , 9 (4), 335-344.

Scherf, A., Schuster, C., Marx, P., Gärber, U., Konstantinidou, D.S. and Schmitt , A. (2010) Control of downy mildew (Pseudoperonospora cubensis) of greenhouse grown cucumbers with alternative biological agents. Communications in Agricultural and Applied Biological Sciences, 75, 541-555.

Schuster, C., Konstantinidou, D.S. and Schmitt, A. (2010) Glycyrrhiza glabra extract protects plants against important phytopathogenic fungi. Communications in Agricultural and Applied Biological Sciences, 75, 531-540.

Shafeek, M.R., Helmy, Y.I., Omer, N.M. and Rizk, F.A. (2013) Effect of foliar fertilizer with nutritional compound and humic acid on growth and yield of broad bean plants under sandy soil conditions. Journal of Applied Sciences Research, 9 (6), 3674-3680.

Sharaf, A.M., Farghal, I.I. and Sofy, M.R. (2009) Response of broad bean and lupin plants to foliar treatment with boron and zinc. Australian Journal of Basic and Applied Sciences, 3 (3), 2226-2231.

Srivastava S., Darokar M.P. and Khanuja S.P.S. (2009) Antifungal activity of Glycyrrhiza glabra extracts and its active constituent Glabridin. Phytotherapy Research, 23, 1190-1193.

Wandruszka, Ray von (2006) Phosphorus retention in calcareous soils and the effect of organic matter on its mobility. Department of Chemistry, University of Idaho, Moscow, ID 83844-2343, USA, Geochemical Transactions, 7:6 
Zuhair A.D. and Mohammed, A.H.A. (2010) Effect of foliar spray of zinc and liquorice root extract on some vegetative and flowering growth parameters of two strawberry varieties. Journal of Agriculture Rivers, 38 (1),1-10.

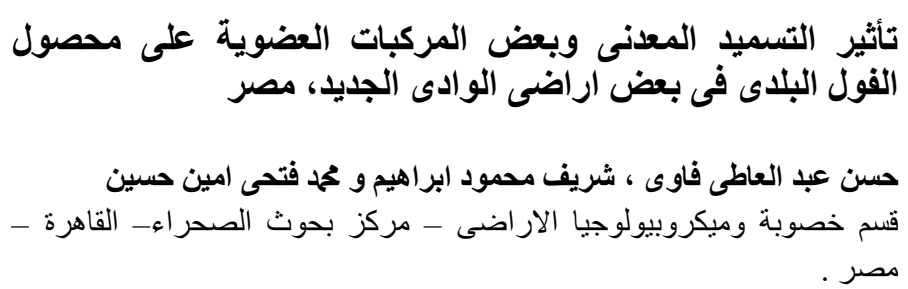

اقيمت التجارب الحقلية خلال عامين متتالين فى قرية القصر تمثل الاراضى الطينية

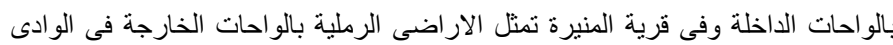

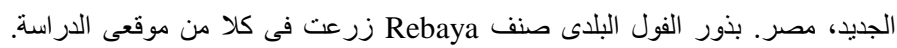

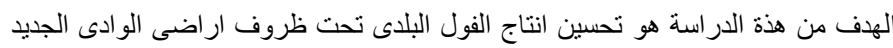

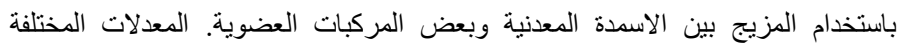

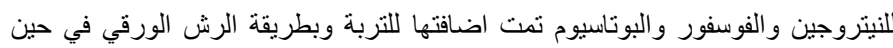

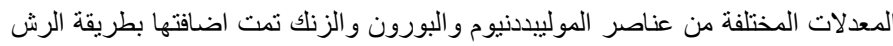

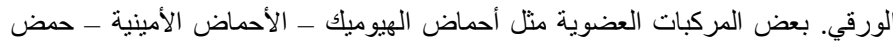
الأسكوربيك - مستخلص العرق سوس، تمت اضافتها مع الأسمدة المعدنية.

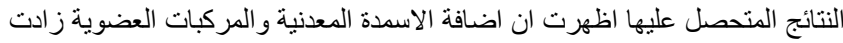

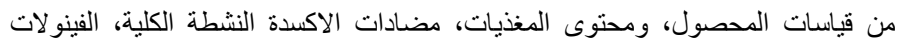

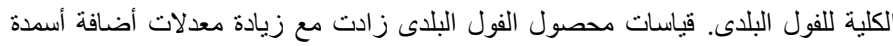

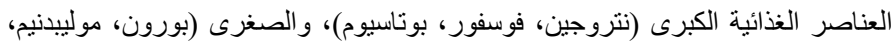

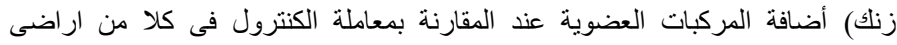

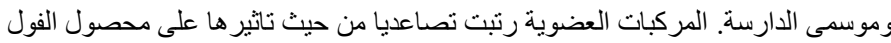

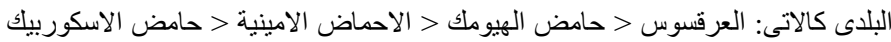

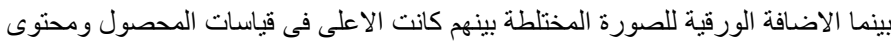

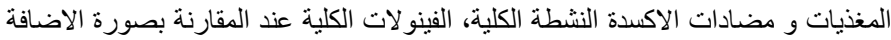

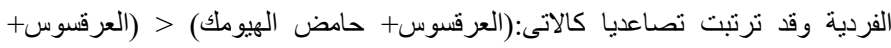

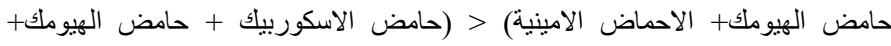

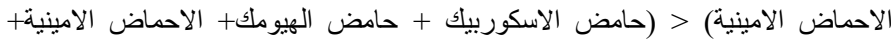

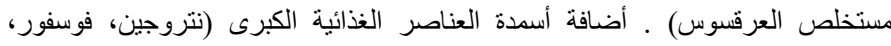

Egypt. J. Soil Sci. 56, No. 1 (2016) 
EFFECT OF MINERAL FERTILIZATION AND SOME ORGANIC COMPOUNDS 91

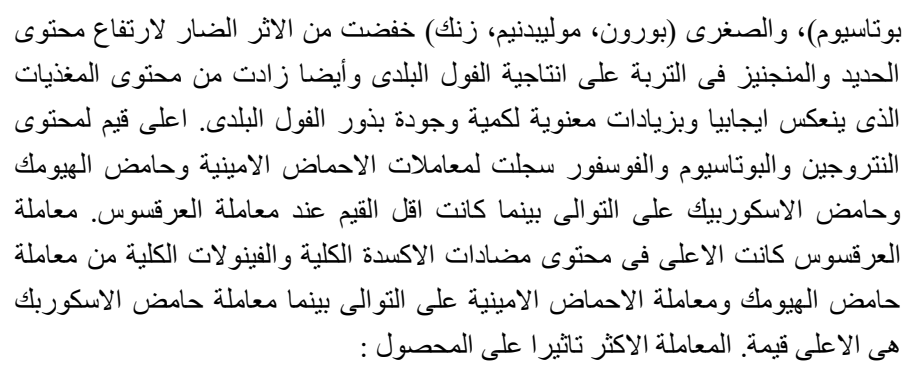

